BOOK REVIEW:

A RESPONSE TO ERWIN DEKKER

BY GÁBOR BÍRÓ*

* Budapest University of Technology and Economics. Contact:

biro.gabor.istvan@,filozofia.bme.hu

This "preprint" is the accepted typescript of a book review that is forthcoming in revised form, after minor editorial changes, in the Journal of the History of Economic Thought (ISSN: 1053-8372), issue TBA. Copyright to the journal's articles is held by the History of Economics Society (HES), whose exclusive licensee and publisher for the journal is Cambridge University Press (https://www.cambridge.org/core/journals/journal-of-the-history-of-economic-thought). This preprint may be used only for private research and study and is not to be distributed further.

The preprint may be cited as follows:

Bíró, Gábor. A Response to Erwin Dekker. Journal of the History of Economic Thought (forthcoming). Preprint at SocArXiv, osf.io/preprints/socarxiv 


\section{A Response to Erwin Dekker}

I completely agree with Erwin Dekker that this book is not a comprehensive account of the economic ideas of Michael Polanyi. I've never claimed it is. Actually, the scope of this endeavour is quite narrow in terms of Polanyi's economic ideas. It is limited to Polanyi's vision of his economics film ("democracy by enlightenment through the film" (Polanyi 1935, p. 1)) mirrored in the two consecutive versions of his motion picture, An Outline of the Working of Money (1938), and Unemployment and Money: The Principles Involved (1940), as well as in his Keynesian textbook, Full Employment and Free Trade (1945) which he considered as a textual remake of his film that tells a similar story (the relation between monetary circulation and unemployment and the role of the state in their management) in a somewhat similar way (cartoonish visual representations). The book is explicit about being non-comprehensive. The "primary aim of this book is to present the personal road taken by Polanyi's postmodern economics and his related film" (Bíró 2019,p. 1) in various social worlds by a careful and detailed analysis of Polanyi's correspondence.

Similarly to Dekker, I do think that there are additional important Polanyian concepts to address (economic planning, spontaneous order, tacit knowing, etc.) and that there are other promising approaches to be used. Actually, I've been working on some of these since submitting this manuscript. But with this book, my aim was to provide my readers with an inside view of the rise and fall of the vision that was based on Polanyi's pioneering educational project. That is, to bring my readers as close as possible to what is being pursued, to let the analysed thinkers use their own words and interpretations instead of being severely constrained by a highly circumscribed central narrative. And one can only attempt this with an extensive use of archival materials. If one presumes that ideas and concepts do not appear first in a full-fledged form, but being developed in a gradual way through discussions then one should go beyond the published materials (to exchanged letters, notes and brief sketches) in order to be able to portray the evolution of these ideas and concepts. In my opinion, the maturing of the ideas and concepts is important and inherent to their true meaning. Moreover, taking this road provides another benefit: it may show how various possible meanings of the same idea struggle with each other as well as with meanings of other alternative ideas. It shows the private life of ideas before they find their way into the public canon of the field. And that is where one finds fascinating things.

What stroke me the most about Dekker's review is that he did not say a word about science and technology studies (STS). This is quite unexpected because the book was explicitly framed as a piece which relies on an STS concept (sociotechnical imaginaries by Sheila Jasanoff and Sang-Hyun Kim (2015)) and sought to show how Polanyi's sociotechnical vision about his film ("democracy by enlightenment through the film") clashed with visions of others and struggled, in various social worlds, to become a widely held public imaginary. Eventually, Polanyi's sociotechnical vision failed to become an imaginary. But, from the early thirties to the mid-forties, it had potential to become one. Polanyi envisioned to induce large-scale democratic changes with his educational film. His innovation (audiovisual economics) may not turned out as well as expected, but the bitter end of a project does not necessarily mean that nothing can be learned from it. The film might not be picked up by the general public, and, without doubt, failed to revolutionize economics education and to reform democracy. But the trial and error process of trying to do so might be illuminating not just for Polanyi scholars but also for those interested in the life and death of social visions about scientific or technological advancements. Perhaps, if Dekker would have paid more attention to this narrative being framed as a case in point of sociotechnical visions he had been less surprised by what had and what had not been included in the book. The review lacks references to other specific STS and HPS concepts mentioned in the introduction (e.g., obligatory passage point, interessement (Callon 1986); boundary object (Star-Griesemer 1989); actornetwork theory, immutable mobiles (Latour 1990); co-production (Jasanoff 2004); vanguard vision (Hilgartner 2015)) that were used to explain the narrative decisions made in the book.

Dekker remained silent on one more important thing: that the book aimed to challenge Mirowski's claim about the univocal transformation of economic protoenergetics into cyborg economics (2002) in the period. It argued that Polanyi's anti-utilitarian and anti-mechanistic economics did not fit into any of these categories. It was a counterexample that has been gradually worked out through correspondence with several intellectuals (not just economists) within circa two decades. Polanyi's personal economics was pretty much a reaction to the undoubtedly dominant parallel tendencies of dehumanization and mathematization of economic thinking in the era. This makes it worthy of study, and perhaps suggests that Mirowski's portrayal 
of the period might use some fine-tuning. The book may or may not succeed in presenting a counterexample that challenges Mirowski's account, but saying nothing about this (perhaps too) ambitious endeavour is either being sloppy or missing a clear shot.

I am very grateful for Dekker for the insightful comments about what other connections might be explored. Both Polanyi's relationship with the Austrian school (von Mises, Hayek, Kirzner, etc.) and the later literature on policentricity (Ostrom) seems very promising and I agree that these bridges should be built. Also, Polanyi's involvement with the Mont Pèlerin Society is an exciting topic (actually, Polanyi might have been the first signatory, or, with other words, the first founding father of the Society) that needs inquiries with a somewhat wider scope. These accounts should focus less on digging deep and more on comparing the related ideas of co-operating and competing thinkers. Similarly to Dekker, I cannot wait to read some of these.

Gábor Bíró
Budapest University of Technology and Economics

\section{REFERENCES}

Bíró, G. 2019. The Economic Thought of Michael Polanyi, Abingdon: Routledge.

Callon, M., 1986. "Some elements of a sociology of translation: domestication of the scallops and the fisherman in St Brieuc Bay." In K. Knorr-Cetina \& A. V. Cicourel, eds. Advances in Social Theory and Methodology: Toward an Integration of Micro and Macro-Sociologies. Boston: Routledge \& Kegan Paul, pp. 196-223.

Hilgartner, Stephen. 2015. "Capturing the Imaginary: Vanguards, Visions, and the Synthetic Biology Revolution." Chapter 3 in Science and Democracy: Knowledge as Wealth and Power in the Biosciences and Beyond, edited by Stephen Hilgartner, Clark Miller, and Rob Hagendijk. Abingdon, Oxon: Routledge.

Jasanoff, Sheila, ed. 2004. States of Knowledge: The Co-Production of Science and Social Order. London: Routledge.

Jasanoff, Sheila - Kim, Sang-Hyun. 2015. Dreamscapes of Modernity: Sociotechnical Imaginaries and the Fabrication of Power. Chicago/London: The University of Chicago Press.

Latour, Bruno. 1990. "Drawing Things Together." Pp. 19-68 in Representation in Scientific Practice, edited by Michael Lynch and Steve Woolgar. Cambridge, MA: MIT Press.

Mirowski, Philip. 2002. Machine Dreams: Economics Becomes a Cyborg Science. Cambridge: Cambridge University Press.

Polanyi, Michael. 1935. A letter of 13th December 1935 from Michael Polanyi to John Grierson, Michael Polanyi Papers, Box 3 , Folder 5, Special Collections, University of Chicago Library.

- 1938. An Outline of the Working of Money, G.B. Instructional Ltd. 1940. Unemployment and Money: The Principles Involved. G.B. Instructional Ltd. 1945. Full Employment and Free Trade. Cambridge: Cambridge University Press.

Star, S. L. and J. R. Griesemer. 1989. 'Institutional Ecology, 'Translations,' and Boundary Objects: Amateurs and Professionals in Berkeley's Museum of Vertebrate Zoology, 1907 - 1939." Social Studies of Science 19: 387-420. 